\title{
Gérard Gengembre, Mme de Staël: de la littérature ou des belles-lettres?
}

\section{Rita Severi}

\section{Q OpenEdition}

1 Journals

\section{Edizione digitale}

URL: http://journals.openedition.org/studifrancesi/9580

DOI: 10.4000/studifrancesi.9580

ISSN: 2421-5856

\section{Editore}

Rosenberg \& Sellier

\section{Edizione cartacea}

Data di pubblicazione: 1 décembre 2007

Paginazione: 672

ISSN: 0039-2944

\section{Notizia bibliografica digitale}

Rita Severi, «Gérard Gengembre, Mme de Staël: de la littérature ou des belles-lettres?», Studi Francesi

[Online], 153 (LI | III) | 2007, online dal 30 novembre 2015, consultato il 13 janvier 2021. URL: http:// journals.openedition.org/studifrancesi/9580 ; DOI: https://doi.org/10.4000/studifrancesi.9580

Questo documento è stato generato automaticamente il 13 janvier 2021.

\section{(c) $(1) \&$}

Studi Francesi è distribuita con Licenza Creative Commons Attribuzione - Non commerciale - Non opere derivate 4.0 Internazionale. 


\title{
Gérard Gengembre, Mme de Staël: de la littérature ou des belles-lettres?
}

\author{
Rita Severi
}

\section{NOTIZIA}

GÉRARD GENGEMBRE, Mme de Staël: de la littérature ou des belles-lettres?, in Bonnes Lettres /

Belles Lettres, actes des colloques du Centre d'Études et de Recherches Éditer /

Interpréter de l'Université de Rouen, 26 et 27 avril 2000 et 6-7 février 2003, textes

réunis par C. POULOUIN et J.-C. ARNOULD, Paris, Champion, 2006, pp. 429-437.

1 Dopo una breve introduzione metodologica sulla definizione di «littérature» secondo i testi di riferimento dell'Illuminismo, quali il Dictionnaire de l'Académie (ed. 1740 a cura di De Jancourt) e il Supplément de l'Encyclopédie, dove la voce fu redatta da Marmontel, Gérard Gengembre si appresta a illustrare succintamente sia la posizione dello scrittore che lo statuto della letteratura in due testi di Mme de Staël: Des Circonstances actuelles qui peuvent terminer la Révolution et des principes qui doivent fonder la République en France (1798, ma si rimanda all'ed. di L. Omacini, Genève, Droz 1979) e De la Littérature.

2 Senza dubbio, ammette l'autore, non si può contestare il ruolo decisivo di Mme de Staël nell'elaborazione della nozione moderna di letteratura, e del suo apporto nel ridefinire l'uomo di lettere con la figura dello «scrittore». Eppure, soprattutto nella prima opera, ella rimane legata a una concezione classica delle «belles-lettres», non solo come «letteratura» ma anche come "sapere». Come l'autore, assieme a Jean Goldzink, ha precedentemente dimostrato nella sua edizione delle opere di Mme de Staël (Flammarion, 1991), durante l'Illuminismo era molto più in auge il sintagma «gens de lettres» che la parola «littérature» e la scrittrice, d'accordo anche con alcuni contemporanei, come L.-S. Mercier, propende per «l'écrivain d'imagination». Ella sostiene, infatti, che alla nuova figura dello scrittore spetta il compito di dipingere la società e d'impegnare la sua sensibilità nel far rivivere $i$ «mouvements de la nature». In sostanza, nulla dovrebbe separare la littérature d'idées et d'imagination. 
3 Nel secondo testo citato la scrittrice assume una posizione chiaramente politica fin dall'assioma iniziale che recita: «Les progrès de la littérature sont nécessaires à l'établissement et à la conservation de la liberté». Dunque ella assegna agli scrittori una nuova missione: in mancanza di una letteratura rivoluzionaria bisognerà creare la letteratura repubblicana. Questo «engagement» prevede che lo scrittore diventi un repubblicano modello, il quale, in attesa della letteratura rigenerata, provveda a fornire una «littérature de la compensation». Nell'opera più matura, De l'Allemagne, Mme de Staël riuscirà a fondere in modo dialettico il romanticismo, il cosmopolitismo e le idee della rivoluzione «relançant le progrès littéraire dans une Histoire complète, chaotique, mais engagée de manière irréversible sur la voie glorieuse de la perfectibilité réaffirmée» (p. 437). 